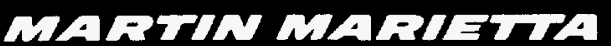

ENVIRONMENTAL

RESTORATION

PROGRAM

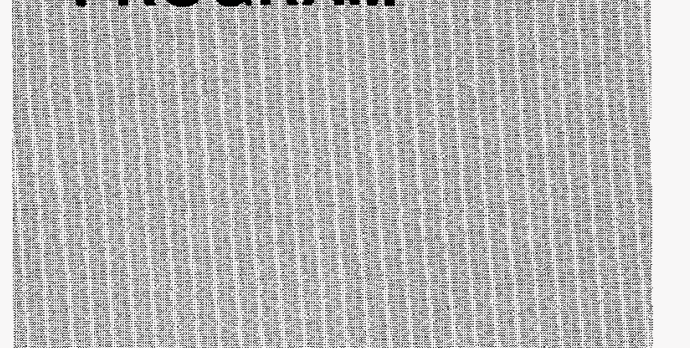

II)

(1)

W.

1.

IIt)

TIII)

P.

\section{赔}

\section{tons}

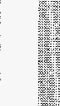

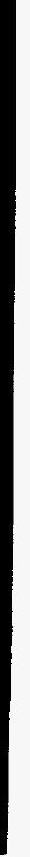

.

\section{MANAGED BY}

MARTIN MARIETTA ENERGY SYSTEMS, ING: FOR THE UNITEO STATES DEPARTMENT OF ENERGY

\section{Bioavailability of Mercury in East Fork Poplar Creek Soils}

\author{
FEREIVED \\ DEC 281995 \\ OSTI
}

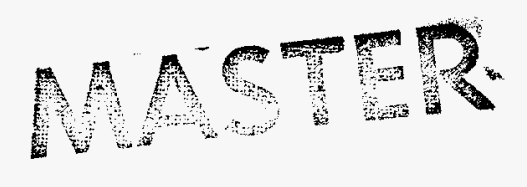




\section{DISCLAMMER}

Portions of this document may be illegible in electronic image products. Images are produced from the best available original document. 
Energy Systems Environmental Restoration Program

Y-12 Environmental Restoration Program

\title{
Bioavailability of Mercury in East Fork Poplar Creek Soils
}

M. O. Barnett

R. R. Turner

Date Issued-May 1995

\author{
Prepared by \\ Environmental Sciences Division \\ Oak Ridge National Laboratory \\ Oak Ridge, Tennessee \\ Prepared for \\ U.S. Department of Energy \\ Office of Environmental Management \\ under budget and reporting code EW 20
}

Environmental Restoration and Waste Management Programs

Oak Ridge Y-12 Plant

Oak Ridge, Tennessee 37831-7101

managed by

MARTIN MARIETTA ENERGY SYSTEMS, INC.

for the

U.S. DEPARTMENT OF ENERGY

under contract DE-AC05-84OR21400 



\section{PREFACE}

This report summarizes an investigation of the bioavailability of mercury in Lower East Fork Poplar Creek (EFPC) floodplain soils as part of the remedial efforts pursuant to the Comprehensive Environment Response, Compensation and Liability Act (CERCLA) of 1980 as amended by the Superfund Amendments and Reauthorization Act (SARA) of 1986 and the Federal Facility Agreement (FFA). This work was performed under Work Breakdown Structure 1.4.12.3.1.04.41, Activity Data Sheet 9304, "Lower East Fork Poplar Creek." An abbreviated version of this report appeared in the Addendum to the East Fork Poplar Creek - Sewer Line Beltway Remedial Investigation Report (DOE/OR/02-1119\&D2/A1/R1). The information presented in this report was used in deriving the Remediation Goal Option (RGO) for EFPC soil. 



\section{CONTENTS}

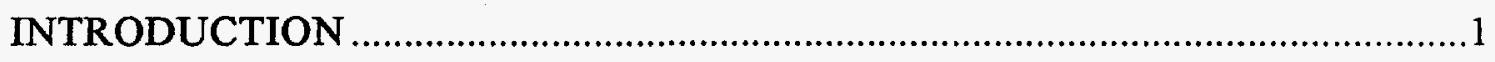

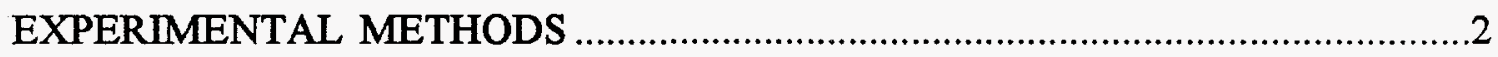

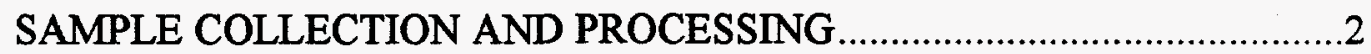

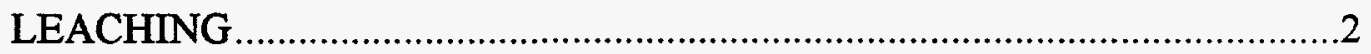

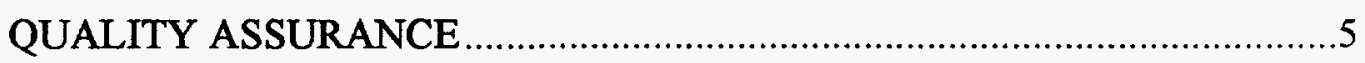

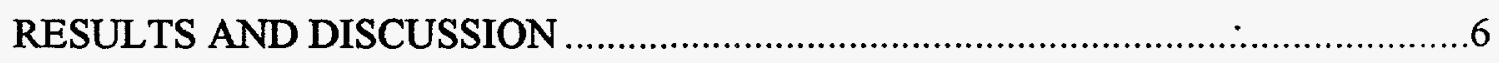

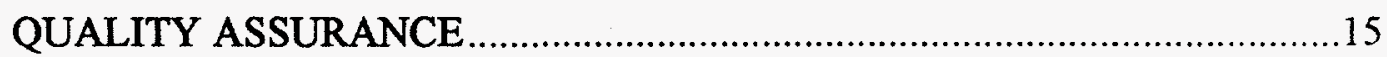

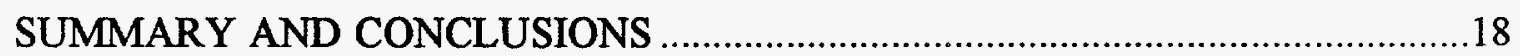

REFERENCES 



\section{FIGURES}

Fig 1.

Fig. 2.

Sample Locations for EFPC. 3

Fig. 3. Mercury versus Sulfur in EFPC Soils.

Fig. 4.

Mercury versus Sulfur in Deep Soils.

\section{TABLES}

Table 1.

Sample Identification, Depths and Description 4

Table 2.

Mercury, Sulfur and Carbon Concentrations in EFPC Soils... 7

Table 3. Mercury, Sulfur and Carbon Molar Concentrations in EFPC Soils.........8

Table 4. Leachate Results for Dry Soils. 13

Table 5.

Leachate Results for Field Moist Soils, Soils at Body Temperature, Soils with Deoxycholic Acid and Mercuric Chloride and Sulfide 14

Table 6. Quality Assurance Data for Solid Samples 16

Table 7. Quality Assurance Data for Leachate Samples. 



\section{SUMMARY}

The initial risk assessment for the East Fork Poplar Creek (EFPC) floodplain in Oak Ridge, Tennessee, a superfund site heavily contaminated with mercury, was based upon a reference dose for mercuric chloride, a soluble mercury compound not expected to be present in the floodplain, which is frequently saturated with water. Previous investigations had suggested mercury in the EFPC floodplain was less soluble and therefore less bioavailable than mercuric chloride, possibly making the results of the risk assessment unduly conservative. A bioavailability study, designed to measure the amount of mercury available for absorption in a child's digestive tract, the most critical risk endpoint and pathway, was performed on twenty soils from the EFPC floodplain. The average percentage of mercury released during the study for the twenty soils was $5.3 \%$, compared to $100 \%$ of the compound mercuric chloride subjected to the same conditions. Alteration of the procedure to test additional conditions possible during soil digestion did not appreciably alter the results. Therefore, use of a reference dose for mercuric chloride in the EFPC risk assessment without inclusion of a corresponding bioavailability factor may be unduly conservative. 


\section{INTRODUCTION}

The floodplain of East Fork Poplar Creek (EFPC) in Oak Ridge, Tennessee is contaminated with mercury from historic releases from the Department of Energy Oak Ridge Y-12 Plant located at the headwaters. The floodplain is currently being investigated as a superfund site (Department of Energy, 1994). The initial risk assessment dose calculations for mercury were based on the compound mercuric chloride, a soluble form of mercury not expected to exist in the environment. Several investigations have suggested the mercury in EFPC soils may be less soluble and therefore less bioavailable than mercuric chloride (e.g. Revis, et al, 1990), making the results of the risk assessment unduly conservative.

A bioavailability study was conducted to determine the fraction of mercury in EFPC soils potentially available for absorption in the human digestive system, the critical pathway of human exposure in this system. The bioavailability study attempted to simulate the human digestive system. The study was adapted from a protocol used in another risk assessment conducted on an old mercury mine (Camp, Dresser \& McKee, 1992), which was designed to mimic the conditions encountered in the human digestive tract (e.g. pH, residence time, solid/solution ratio, etc.). The study was conducted on a suite of soils from the floodplain as well as some pure mercury compounds for comparison purposes. 


\section{EXPERIMENTAL METHODS}

\section{SAMPLE COLLECTION AND PROCESSING}

In January 1994, soil samples were collected at two depths from ten sites (for a total of twenty samples) to represent a range of environmental conditions in the floodplain (Fig. 1). Surface samples were collected within three inches of the surface. Deeper samples were collected in layers historically associated with the highest concentration of mercury in the floodplain. The sample designation, soil description and sample depth are shown in Table 1.

Samples were collected by channel sampling with a stainless steel spatula and spoon, composited by mixing in stainless steel bowls, placed in glass jars, transported back to the laboratory and refrigerated until processing. In the laboratory, samples were air dried in aluminum foil trays, lightly crushed with a clean mortar and pestle and sieved to $2 \mathrm{~mm}$ to remove rocks, roots, etc. The $<2 \mathrm{~mm}$ material was ground in a clean mortar and pestle and sieved to $<180 \mu \mathrm{m}$. Subsamples of the $<180 \mu \mathrm{m}$ material were analyzed for total mercury by SW-846 Method 7471 and total carbon and total sulfur with a LECO carbon/sulfur analyzer.

\section{LEACHING}

One liter polypropylene containers were washed with $2 \mathrm{~N}$ nitric acid, and rinsed with distilled, deionized water. A $0.74 \mathrm{~g}$ portion of each air dried, $<180 \mu \mathrm{m}$ soil was added to one liter of distilled, deionized water adjusted to $\mathrm{pH} 2.5$ with $16 \mathrm{~N}$ hydrochloric acid in the cleaned containers. The samples were shaken continuously. The $\mathrm{pH}$ was rechecked after ten minutes and again after one hour. No pH readjustment was required for any of the samples at $\mathrm{pH}$ 2.5. After four hours of leaching, the $\mathrm{pH}$ of each sample was measured and recorded and the samples were allowed to settle. All samples had a final $\mathrm{pH}$ of $2.5 \pm 0.2$. After twenty-five minutes, $250 \mathrm{ml}$ of the supernatant was poured into cleaned, disposable $0.2 \mu \mathrm{m}$ filter units and filtered. The filtrate was preserved with potassium dichromate in nitric acid prior to analysis for total mercury by $\mathrm{SW}-846$ Method 7470. This treatment simulates the stomach.

The remaining $750 \mathrm{ml}$ of suspension was combined with $250 \mathrm{ml}$ distilled, deionized water to restore the original solid/solution ratio and the $\mathrm{pH}$ was adjusted to 6.5 with 5 and $0.5 \mathrm{~N}$ sodium hydroxide. The samples were shaken while rechecking and readjusting $\mathrm{pH}$ as necessary at ten minutes and one hour. After four hours, the sample $\mathrm{pH}$ was checked and recorded, and the samples were filtered as described above. There were some problems with $\mathrm{pH}$ drifting from 6.5 (particularly down) during the procedure. Of the 46 leachates at $\mathrm{pH} 6.5,25$ had a final $\mathrm{pH}$ of $6.5 \pm 0.2,39$ had a final $\mathrm{pH}$ of $6.5 \pm 0.5$ and all 


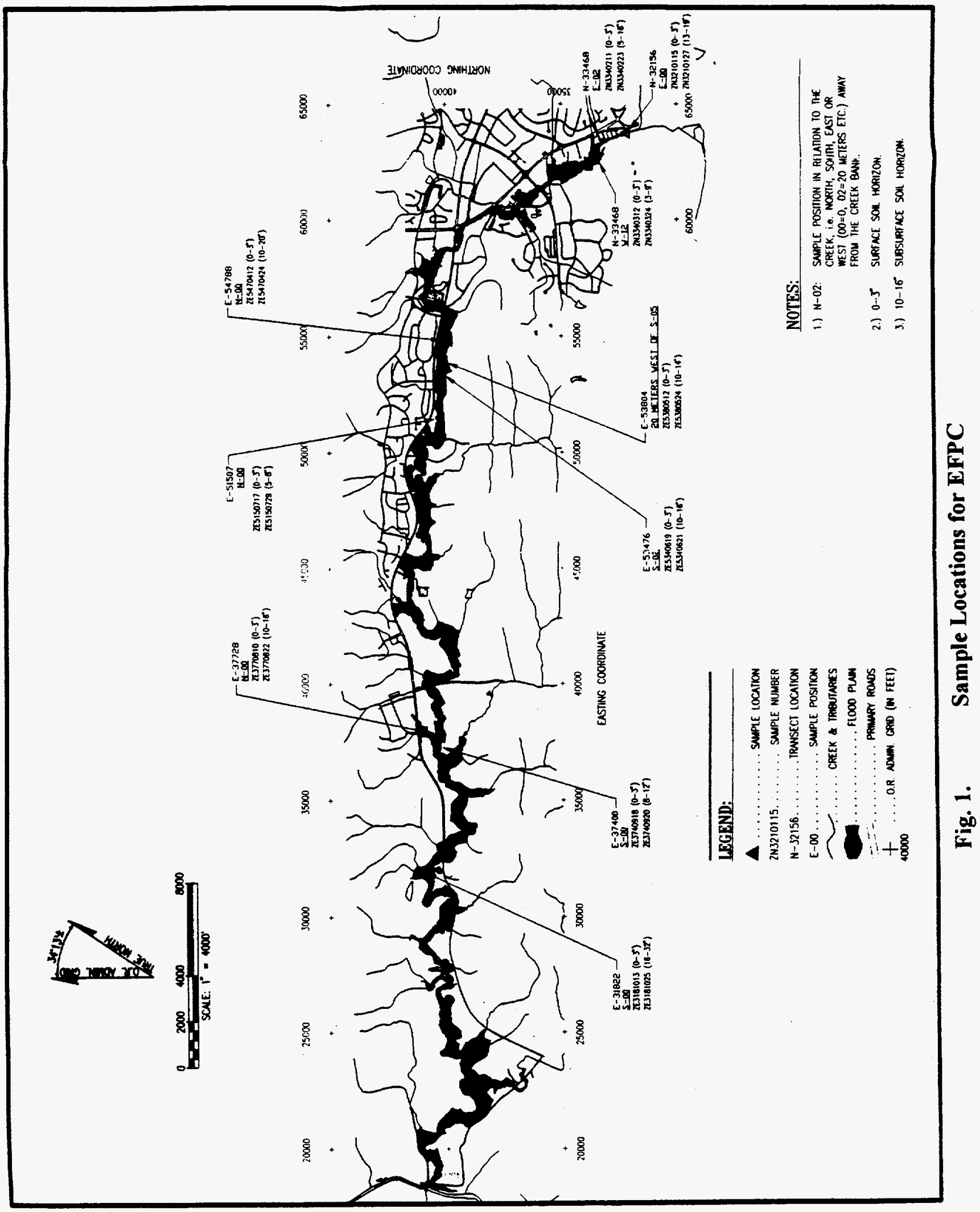


Table 1. Sample Identification, Depths and Description

Sample No. Depth (in) Description

\begin{tabular}{ccl}
\hline ZN3210115 & $0-3$ & Grayish-Brown, Medium Texture \\
ZN3210127 & $13-19$ & Brownish-Gray, Medium Texture \\
ZN3340211 & $0-3$ & Grayish-Brown, Medium Texture \\
ZN3340223 & $5-16$ & Brownish-Gray, Medium Texture \\
ZN3340312 & $0-3$ & Grayish-Brown, Medium \\
ZN3340324 & $3-9$ & Texture, Wetland \\
ZE5470412 & $0-3$ & Dark Gray, Medium Texture \\
ZE5470424 & $10-20$ & Dark Brown, Medium Texture \\
ZE5380512 & $0-3$ & Dark Gray, Medium Texture \\
ZE5380524 & Brown, Fine Texture, Clay, \\
ZE5340619 & $10-14$ & Wetland \\
ZE5340621 & Dark Gray, Medium Texture, \\
ZE5150717 & $0-3$ & Clay \\
ZE5150729 & $10-16$ & Dark Brown, Medium Texture \\
ZE3770810 & Dark Brownish-Gray, Medium \\
ZE3770822 & $0-3$ & Texture \\
ZE3740918 & Dark Brown, Medium Texture \\
ZE3740920 & Dark Gray, Medium Texture \\
ZE3181013 & 5-8 & Dark Brown, Medium Texture \\
ZE3181025 & $0-3$ & Light Brown, Medium Texture \\
& $10-16$ & Dark Brown, Medium Texture \\
& $0-3$ & Dark Brown, Medium Texture \\
& $8-12$ & Dark Brown, Medium Texture \\
& $0-3$ & Clay \\
\hline
\end{tabular}


46 had a pH of $6.5 \pm 1.0$. This treatment simulates the remainder of the gastrointestinal tract.

In order to more closely replicate the conditions of actual soil ingestion, the leaching procedure was also repeated for a few samples of unprocessed field moist soil, soil at body temperature $\left(37^{\circ} \mathrm{C}\right)$, and with $10 \mathrm{mg} / \mathrm{l}$ deoxycholic acid, a common constituent of the human digestive system. Mercuric chloride and two forms of mercuric sulfide, cinnabar and metacinnabar, were also run as controls. The mercuric chloride (Mallinckrodt) and cinnabar were reagent grade (EM Science). The metacinnabar was synthesized in the laboratory, and confirmed by $x$-ray diffraction.

\section{QUALITY ASSURANCE}

Two of the soil samples were submitted in triplicate to measure variability in mercury, sulfur and carbon analysis. Method 7471 also specifies that three $0.2 \mathrm{~g}$ aliquots of each soil be taken for total mercury analysis and thus considerable information on sample homogeneity and analytical precision was obtained. Replicate NIST standard reference material (NIST SRM 2710) soil was also submitted blind to the laboratory for analysis of mercury, sulfur and carbon. Distilled, deionized water and process blanks (distilled, deionized water carried through the leaching procedure) were analyzed for mercury. Three soils were leached in triplicate to measure variability in mercury concentrations in the leachate. 


\section{RESULTS AND DISCUSSION}

The results of total mercury, sulfur and carbon analysis on the dry soil are shown in Tables 2 and 3. Mercury concentrations ranged from $15-2630 \mathrm{mg} / \mathrm{kg}$ and, as expected, were higher for deeper samples in nine of the ten sites. The anomalous site (E-37728) was located near the creek and field observations indicated this site had recently been eroded removing the surface soil and exposing the underlying more highly contaminated soil at the surface.

The predominant form of mercury in EFPC soils has been suggested previously as mercuric sulfide (Revis, et al., $1989 \mathrm{a}, \mathrm{b}$ ). The association of elemental mercury and sulfur in individual soil particles has also been noted (K-25 Technical Division, 1993). The results of the present study further indicate the association between mercury and sulfur in the soils of EFPC, which may influence mercury solubility and bioavailability. As shown in Fig. 2, mercury was significantly correlated $(r=0.84)$ with sulfur in the twenty samples (as discussed below, this correlation was due predominately to the deeper samples). In nineteen of the twenty samples, sufficient sulfur was present to bind all of the mercury as mercuric sulfide, with an average of almost seven times as much sulfur as mercury on a molar basis. In one sample, the concentration of mercury exceeded the concentration of sulfur on a molar basis by approximately $20 \%$, indicating all the mercury in this sample can not be mercuric sulfide. One other sample (ZN3210127) clearly deviated from the mercury-sulfur relationship exhibited by the other samples. By removing this sample from the regression, the mercury-sulfur correlation improves significantly $(r=0.92)$ for the other nineteen soils. This sample, the most upstream sample taken (i.e. closest to the source), was apparently geochemically different from the other samples, containing the highest concentration of mercury, and leaching significantly more mercury than the other samples. Carbon has also been show to be strongly associated with mercury in the environment (Andren and Harriss, 1975). However, the correlation between carbon and mercury in EFPC soils is weak $(\mathrm{r}=0.59)$.

There was a significant difference between the association of mercury and sulfur in the surface samples compared to the samples taken at depth. As shown in Fig. 3, total mercury was well correlated $(r=0.945)$ with total sulfur in the deep samples. The correlation $(r=0.528)$ was not as good in the surface samples as shown in Fig. 4. In analyzing the surface and deep samples, the sample which clearly deviated from the mercury-sulfur relationship was not included, and the surface sample from the area where the original surface had been eroded (site E-37728) was included in the deep samples. Several geochemical reasons for the better mercury-sulfur correlation at depth can be postulated. The formation and stability of mercuric sulfide is favored in reducing environments which may occur more favorably in the deeper soils. Alternatively, the deeper mercury concentration peaks are co-depositional with the early operation of the Y-12 plant. Other sulfur rich materials may have been deposited during this same time frame, and coal fragments and fly ash are readily visible in the deeper soils. 
Table 2. Mercury, Sulfur and Carbon Concentrations in EFPC Soils

\begin{tabular}{|c|c|c|c|}
\hline Sample No. & $\mathrm{Hg}(\mathrm{mg} / \mathrm{kg})$ & $\mathrm{S}(\mathrm{mg} / \mathrm{kg})$ & $\mathrm{C}(\mathrm{mg} / \mathrm{kg})$ \\
\hline ZN3210115 & 260 & 150 & 65000 \\
\hline ZN3210127 & 2630 & 683 & 44300 \\
\hline ZN3340211 & 270 & 300 & 59000 \\
\hline ZN3340223 & 1900 & 900 & 68000 \\
\hline $\mathrm{ZN} 3340312$ & 230 & 350 & 93000 \\
\hline ZN3340324 & 2100 & 1600 & 110000 \\
\hline ZE5470412 & 85 & 140 & 40000 \\
\hline ZE5470424 & 1300 & 650 & 81000 \\
\hline ZE5380512 & 67 & 110 & 23000 \\
\hline ZE5380524 & 2100 & 1700 & 120000 \\
\hline ZE5340619 & 140 & 30 & 35000 \\
\hline ZE5340621 & 1200 & 490 & 69000 \\
\hline ZE5150717 & 230 & 150 & 33000 \\
\hline ZE5150729 & 900 & 320 & 50000 \\
\hline ZE3770810 & 480 & 200 & 30000 \\
\hline ZE3770822 & 15.3 & 26.7 & 13600 \\
\hline Z43740918 & 55 & 120 & 25000 \\
\hline ZE3740920 & 780 & 220 & 23000 \\
\hline ZE3181013 & 28 & 150 & 38000 \\
\hline ZE3181025 & 390 & 50 & 12000 \\
\hline mean & 758 & 417 & 51600 \\
\hline
\end{tabular}


Table 3. Mercury, Sulfur and Carbon Molar Concentrations in EFPC Soils

Sample No. $\mathrm{Hg}(\mathrm{mmol} / \mathrm{kg}) \quad \mathrm{S}(\mathrm{mmol} / \mathrm{kg}) \quad \mathrm{C}(\mathrm{mol} / \mathrm{kg}) \quad \mathrm{S} / \mathrm{Hg}(\mathrm{mol} / \mathrm{mol})$

\begin{tabular}{ccccc}
\hline ZN3210115 & 1.3 & 4.7 & 5.4 & 3.6 \\
ZN3210127 & 13.1 & 21.3 & 3.7 & 1.6 \\
ZN3340211 & 1.3 & 9.4 & 4.9 & 7.0 \\
ZN3340223 & 9.5 & 28.1 & 5.7 & 3.0 \\
ZN3340312 & 1.1 & 10.9 & 7.8 & 9.5 \\
ZN3340324 & 10.5 & 49.9 & 9.2 & 4.8 \\
ZE5470412 & 0.4 & 4.4 & 3.3 & 10.3 \\
ZE5470424 & 6.5 & 20.3 & 6.8 & 3.1 \\
ZE5380512 & 0.3 & 3.4 & 1.9 & 10.3 \\
ZE5380524 & 10.5 & 53.0 & 10.0 & 5.1 \\
ZE5340619 & 0.7 & 0.9 & 2.9 & 1.3 \\
ZE5340621 & 6.0 & 15.3 & 5.8 & 2.6 \\
ZE5150717 & 1.1 & 4.7 & 2.8 & 4.1 \\
ZE5150729 & 4.5 & 10.0 & 4.2 & 2.2 \\
ZE3770810 & 2.4 & 6.2 & 2.5 & 2.6 \\
ZE3770822 & 0.1 & 0.8 & 1.1 & 10.9 \\
Z43740918 & 0.3 & 3.7 & 2.1 & 13.7 \\
ZE3740920 & 3.9 & 6.9 & 1.9 & 1.8 \\
ZE3181013 & 0.1 & 4.7 & 3.2 & 33.5 \\
ZE3181025 & 1.9 & 1.6 & 1.0 & 0.8 \\
mean & 3.8 & 13.0 & 4.3 & 6.6 \\
\hline
\end{tabular}




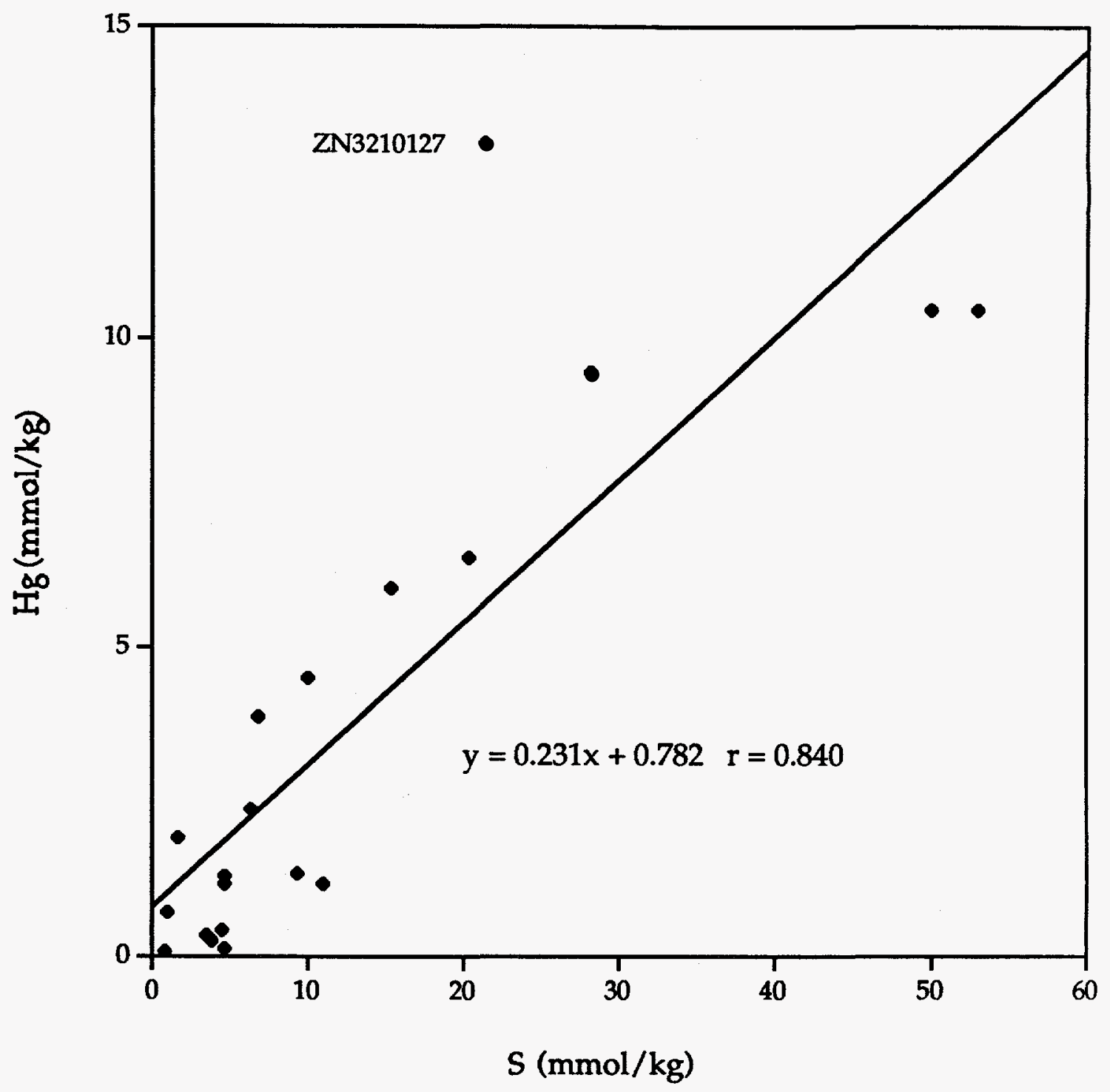

Fig. 2. Mercury versus Sulfur in EFPC Soils. 


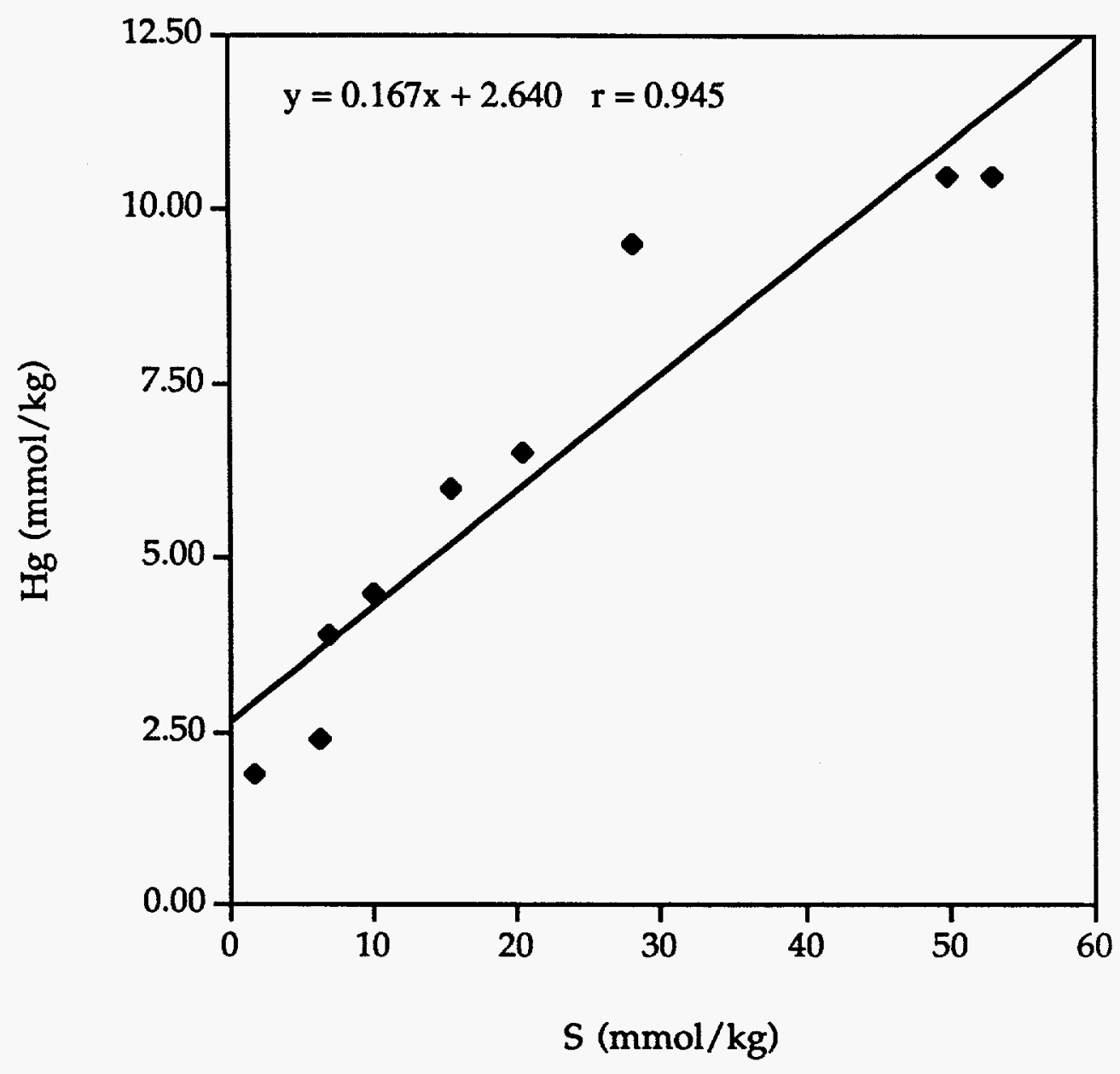

Fig. 3. Mercury versus Sulfur in Deep Soils. 


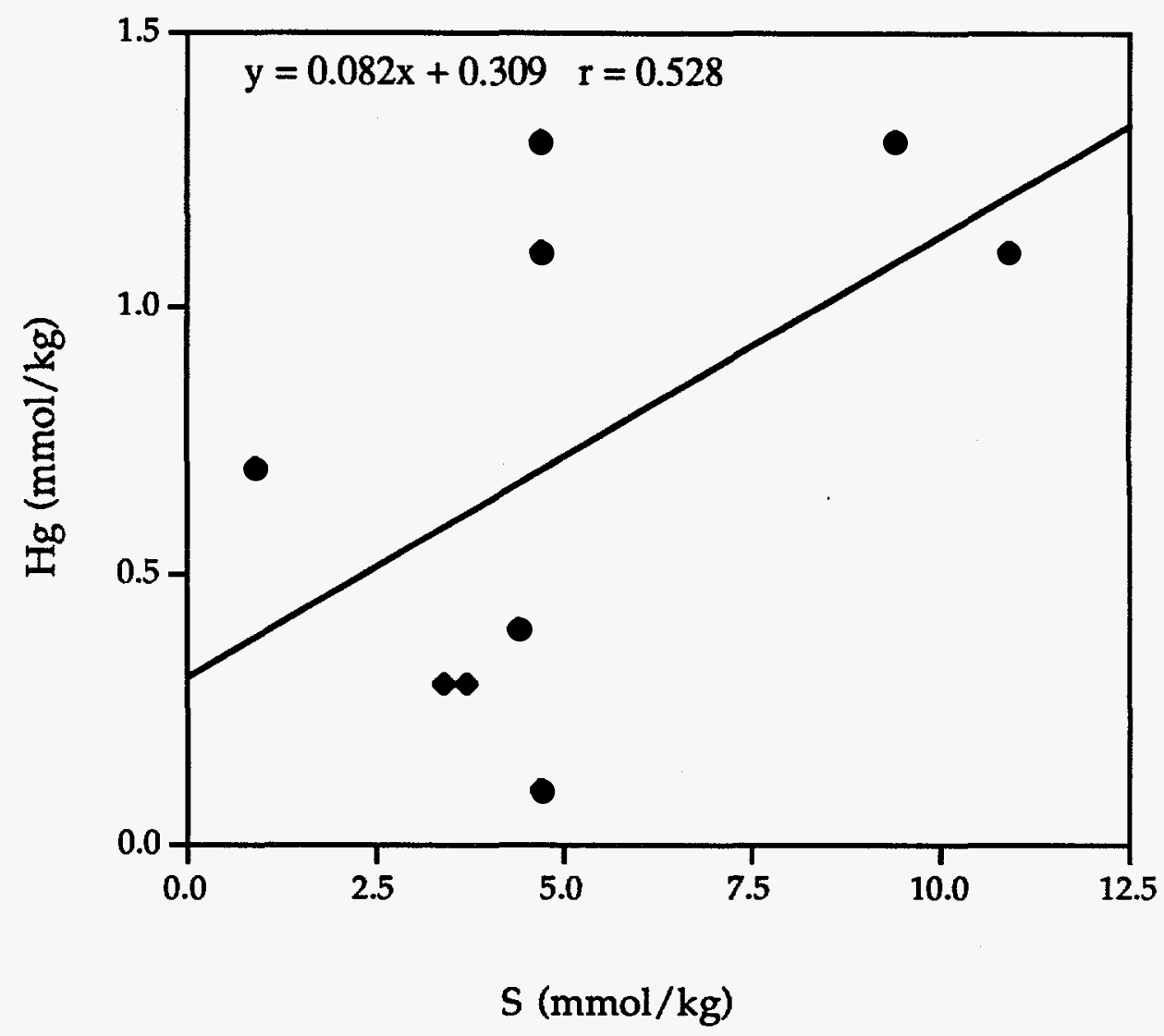

Fig. 4. Mercury versus Sulfur in Surface Soils. 
The results of the leaching study for the twenty soil samples are shown in Table 4 . The percentage leached at $\mathrm{pH} 6.5$ is corrected for the soluble mercury lost from the sample when decanting the supernatant for filtration at $\mathrm{pH} 2.5$. The total percent soluble mercury is simply the sum of the percent soluble at both $\mathrm{pH}$ values and represents a worst case scenario, since some of the mercury in the soil is undoubtedly soluble at both $\mathrm{pH}$ values and is double counted in the simple summation.

In nineteen of the twenty samples, the mercury was not significantly (as a percentage) extracted at either $\mathrm{pH}$. The maximum concentration of mercury in the leachates was $77 \mu \mathrm{g} /$. Less than $5 \%$ of the mercury was solubilized in fifteen of the samples. Total soluble mercury in the nineteen samples ranged from $0.3-14.2 \%$ with an average of $3.2 \%$. For sample $Z N 3210127$, the soluble mercury concentration was 570 and $300 \mu \mathrm{g} / \mathrm{l}$ at $\mathrm{pH} 2.5$ and 6.5 respectively for a total of $45.9 \%$ soluble mercury. The high leachate concentrations for the sample are thought to reflect differences in the form of mercury in the sample. As noted earlier, this sample was an outlier with respect to the otherwise good correlation between total mercury and total sulfur. In addition, this was the only sample among twenty which exhibited detectable mercury vapor in the sample headspace. Including this sample, the average percent mercury leached from the twenty samples was $5.3 \%$.

The presence of mercuric sulfide or a mercury-sulfur association in the soils may be a reason for the low solubility and bioavailability of mercury in the EFPC soils, since the one sample which did not readily conform to the mercury-sulfur correlation was also the sample which had the highest mercury concentrations in the leachate. However, the average percentage leached for the deep samples (3.6\%) was higher than for the surface samples (1.6\%), though the deep samples exhibited a better mercury-sulfur correlation. However, this be indicative of the more water soluble mercury forms being preferentially removed in the surface soils by water infiltration.

The leaching procedure was also conducted for five samples at body temperature ( 37 ${ }^{\circ} \mathrm{C}$ ), four field moist soils and two samples with $10 \mathrm{mg} / 1$ deoxycholic acid, a common constituent of the human digestive tract. The samples were selected to more realistically simulate uptake via soil ingestion and to measure the variability of the results above in conditions more representative of the digestive tract. The results are shown in Table 5. The change in percent solubility for the samples (percent leached minus percent leached from dry soil at $25^{\circ} \mathrm{C}$ from Table 4) ranged from -7.7 to $+1.8 \%$. The differences appear to be within the average experimental error, as discussed later.

Mercuric chloride and mercuric sulfide (cinnabar and metacinnabar) were also subjected to the leaching procedure and the results are shown in Table 5 . The entire mercuric chloride sample dissolved and the leachate concentrations (540 and $450 \mathrm{mg} /$ ) were much higher than the soil leachates, almost one thousand times higher than the highest soil leachate. The concentration of mercury in the metacinnabar sample was 0.05 and 0.5 and was $97 \mu \mathrm{g} / 1$ and $42.0 \mu \mathrm{g} / 1$ in the cinnabar sample at $\mathrm{pH} 2.5$ and 6.5 respectively. The fraction of the sample dissolved was much less than $1 \%$ for both cinnabar and metacinnabar. The cinnabar sample was reagent grade and may have 
Table 4. Leachate Results for Dry Soils

\begin{tabular}{|c|c|c|c|c|c|c|}
\hline Sample & $\begin{array}{c}\text { Soil } \\
\mathrm{Hg}(\mathrm{mg} / \mathrm{kg})\end{array}$ & $\begin{array}{c}\text { Leachate } \\
\mathrm{Hg}(\mu \mathrm{g} / \mathrm{l}) \\
\mathrm{pH} 2.5\end{array}$ & $\begin{array}{c}\text { Leachate } \\
\mathrm{Hg}(\mu \mathrm{g} / \mathrm{l}) \\
\mathrm{pH} 6.5\end{array}$ & $\begin{array}{c}\% \text { Soluble } \\
\text { pH } 2.5\end{array}$ & $\begin{array}{c}\text { \% Soluble } \\
\text { pH } 6.5\end{array}$ & $\begin{array}{c}\% \text { Soluble } \\
\text { Total }^{\mathbf{a}}\end{array}$ \\
\hline$Z N 3210115$ & 260 & 0.70 & 1.00 & 0.4 & 0.5 & 0.9 \\
\hline ZN3210127 & 2630 & 570.00 & 300.00 & 29.3 & 16.6 & 45.9 \\
\hline ZN3340211 & 270 & 0.80 & 0.80 & 0.4 & 0.4 & 0.8 \\
\hline ZN3340223 & 1900 & 77.00 & 20.00 & 5.5 & 1.4 & 6.9 \\
\hline ZN3340312 & 230 & 0.20 & 1.80 & 0.1 & 1.1 & 1.2 \\
\hline ZN3340324 & 2100 & 30.00 & 11.00 & 1.9 & 0.7 & 2.6 \\
\hline ZE5470412 & 85 & 0.20 & 0.40 & 0.3 & 0.6 & 1.0 \\
\hline ZE5470424 & 1300 & 73.00 & 14.00 & 7.6 & 1.5 & 9.1 \\
\hline ZE5380512 & 67 & 1.60 & 1.10 & 3.2 & 2.2 & 5.5 \\
\hline ZE5380524 & 2100 & 26.00 & 8.20 & 1.7 & 0.5 & 2.2 \\
\hline ZE5340619 & 140 & 0.10 & 0.20 & 0.1 & 0.2 & 0.3 \\
\hline ZE5340621 & 1200 & 10.50 & 4.90 & 1.2 & 0.6 & 1.7 \\
\hline ZE5150717 & 230 & 1.80 & 2.60 & 1.1 & 1.5 & 2.6 \\
\hline ZE5150729 & 900 & 13.00 & 3.20 & 2.0 & 0.5 & 2.4 \\
\hline ZE3770810 & 480 & 2.40 & 1.50 & 0.7 & 0.4 & 1.1 \\
\hline ZE3770822 & 15.3 & 1.10 & 0.50 & 9.7 & 4.5 & 14.2 \\
\hline 243740918 & 55 & 0.20 & 0.20 & 0.5 & 0.5 & 1.0 \\
\hline ZE3740920 & 780 & 14.00 & 5.80 & 2.4 & 1.0 & 3.4 \\
\hline ZE3181013 & 28 & 0.03 & 0.20 & 0.1 & 1.0 & 1.1 \\
\hline ZE3181025 & 390 & 6.30 & 1.90 & 2.2 & 0.7 & 2.8 \\
\hline mean & 740 & 41.4 & 19.0 & 3.5 & 1.8 & 5.3 \\
\hline
\end{tabular}

a $(\%$ soluble $\mathrm{pH} 2.5)+(\%$ soluble $\mathrm{pH} 6.5)$ 
Table 5. Leachate Results for Field Moist Soils, Soils at Body Temperature, Soils with Deoxycholic Acid and Mercuric Chloride and Sulfide

\begin{tabular}{|c|c|c|c|c|c|c|c|}
\hline Sample & $\mathrm{Hg}(\mathrm{mg} / \mathrm{kg})$ & $\begin{array}{c}\mathrm{Hg}(\mu \mathrm{g} /) \\
\mathrm{pH} 2.5\end{array}$ & $\begin{array}{c}\mathrm{Hg}(\mu \mathrm{g} / 1) \\
\mathrm{pH} 6.5\end{array}$ & $\begin{array}{c}\text { \% Soluble } \\
\text { pH } 2.5\end{array}$ & $\begin{array}{c}\text { \% Soluble } \\
\text { pH } 6.5\end{array}$ & $\begin{array}{c}\% \text { Soluble } \\
\text { Total }\end{array}$ & $\begin{array}{c}\text { \% Change } \\
\text { in Solubilityb }\end{array}$ \\
\hline ZN3210127-37 & 2630 & 580.00 & 170.00 & 29.0 & 9.2 & 38.2 & -7.7 \\
\hline ZN3210115-37 & 260 & 0.72 & 1.10 & 0.4 & 0.6 & 0.9 & 0.1 \\
\hline ZN3340223-37 & 1900 & 97.00 & 14.00 & 6.9 & 1.0 & 7.9 & 1.0 \\
\hline ZE3740918-37 & 55 & 0.06 & 0.80 & 0.1 & 2.0 & 2.1 & 1.3 \\
\hline ZE5470424-37 & 1300 & 88.00 & 16.00 & 9.1 & 1.7 & 10.8 & 1.8 \\
\hline ZE5470424-W & 1300 & 110.00 & 27.00 & 8.1 & 2.0 & 10.1 & 1.0 \\
\hline ZE3740918-W & 55 & 0.10 & 0.87 & 0.2 & 1.4 & 1.6 & 0.7 \\
\hline ZE3770810-W & 480 & 1.20 & 7.90 & 0.2 & 1.5 & 1.8 & 0.7 \\
\hline ZE3740920-W & 780 & 7.80 & 13.00 & 0.9 & 1.5 & 2.4 & -1.0 \\
\hline ZE3740918-C & 55 & 0.07 & 0.80 & 0.2 & 2.0 & 2.1 & 1.3 \\
\hline ZE3740920-C & 780 & 6.50 & 1.10 & 1.1 & 0.2 & 1.3 & -2.1 \\
\hline $\mathrm{HgCl}_{2}$ & & $540,000.00$ & $450,000.00$ & 98.8 & 109.3 & 100.0 & \\
\hline cinnabar & & 97.00 & 42.00 & 0.0 & 0.0 & 0.0 & \\
\hline metacinnabar & & 0.05 & 0.50 & 0.0 & 0.0 & 0.0 & \\
\hline
\end{tabular}

a. 37 represents sample leached at $37^{\circ} \mathrm{C}, \mathrm{W}$ represents field moist soil and $\mathrm{C}$ represents with $10 \mathrm{mg} / \mathrm{l}$ deoxycholic acid.

b. Total \% leached - Total \% leached from dry soil at $25^{\circ} \mathrm{C}$ from Table 4. 
contained other more soluble mercury phases (such as an oxidized surface coating) whereas the metacinnabar had been recently precipitated and washed with distilled water.

\section{QUALITY ASSURANCE}

The quality assurance data for soil analysis are shown in Table 6. Three replicates each were analyzed for two of the soils. The coefficient of variation (COV), the ratio of the standard error to the mean expressed as a percentage, for the two soils were 3.8 and $2.2 \%$ for total mercury indicating excellent precision. Note that EPA Method 7471 requires solids to be analyzed in triplicate and thus all the values for all twenty soils are the mean of these measurements. The COV for two soil total carbon analyses were 4.2 and $3.4 \%$ also indicating excellent precision. The precision for the total sulfur analysis was not as good, with COV for two samples of 53.9 and $21.9 \%$. The mercury values reported for two blind NIST standard reference materials agreed within -1.8 and $-14.1 \%$ of the reference value indicating acceptable accuracy (the results of all twenty soils agreed within approximately $1 \%$ with the mercury results for the same soils analyzed for the EMSL speciation study (Dobb, et al, 1994). The reported values for carbon agreed with the NIST SRM within -3.3 and $0 \%$ indicating excellent accuracy. The reported values for sulfur, however, only agreed with the NIST SRM within -45.8 and $-92.5 \%$.

The quality assurance data for the aqueous leachate samples are shown in Table 7. All source water and process blanks had mercury concentrations less than the minimum detectable concentration of $0.2 \mu \mathrm{g} /$ (not shown). The precision of the leachate mercury concentrations based on three replicates each for five samples varied with COV ranging from $0-48.1 \%$. The larger COV could have probably been reduced by rejection of one outlier.

The quality assurance data for all analyses was acceptable to excellent, with the exception of the analysis of total sulfur in soils, which did not have ideal accuracy nor precision. The LECO sulfur analyzer measures the amount of sulfur by conversion to sulfur dioxide during high temperature combustion with oxygen. However, the extent of conversion to sulfur dioxide is dependent on the soil matrix (Huffman and Stuber, 1985). In addition, sulfur is apparently a problematic element to measure in environmental samples. Measurement of the amount of sulfur in three humic substances (a common component of natural samples) by four different laboratories consistently produced COV of greater than $50 \%$ (Huffman and Stuber, 1985). The absolute values (accuracy) of sulfur measured in the soil samples are suspect. However, since the measurements were conducted on twenty soils, precision errors would tend to cancel out in examining trends. Therefore, although the sulfur content of individual soils are suspect, the trends identified (i.e. increasing sulfur content with mercury content) are valid. 
Table 6. Quality Assurance Data for Solid Samples

\begin{tabular}{|c|c|c|c|c|}
\hline Sample & $\begin{array}{l}\text { Element- } \\
\text { Replicate }\end{array}$ & $\begin{array}{l}\text { Concentration } \\
(\mathrm{mg} / \mathrm{kg})\end{array}$ & $\begin{array}{c}\text { Mean } \\
(\mathrm{mg} / \mathrm{kg})\end{array}$ & $\begin{array}{c}\text { COV } \\
\%\end{array}$ \\
\hline \multirow[t]{9}{*}{ ZE3770822 } & $\mathrm{Hg}-1$ & 15 & 15.3 & 3.8 \\
\hline & $\mathrm{Hg}-2$ & 16 & & \\
\hline & $\mathrm{Hg}-3$ & 15 & & \\
\hline & S-1 & 16 & 26.7 & 53.9 \\
\hline & S-2 & 43 & & \\
\hline & S-3 & 21 & & \\
\hline & C-1 & 13,000 & 13,700 & 4.2 \\
\hline & $\mathrm{C}-2$ & 14,000 & & \\
\hline & $C-3$ & 14,000 & & \\
\hline \multirow[t]{9}{*}{ ZN3210127 } & $\mathrm{Hg}-1$ & 2700 & 2630 & 2.2 \\
\hline & $\mathrm{Hg}-2$ & 2600 & & \\
\hline & $\mathrm{Hg}-3$ & 2600 & & \\
\hline & S-1 & 560 & 683 & 21.9 \\
\hline & $S-2$ & 850 & & \\
\hline & S-3 & 640 & & \\
\hline & $C-1$ & 43,000 & 44,300 & 3.4 \\
\hline & $\mathrm{C}-2$ & 46,000 & & \\
\hline & $\mathrm{C}-3$ & 44,000 & & \\
\hline
\end{tabular}

NIST SRM Element Concentration Standard Value \% difference $(\mathrm{mg} / \mathrm{kg}) \quad(\mathrm{mg} / \mathrm{kg})$

\begin{tabular}{ccccc} 
Replicate 1 & Hg & 28 & 32.6 & -14.1 \\
& $\mathrm{~S}$ & 1,300 & 2,400 & -45.8 \\
& $\mathrm{C}$ & 29,000 & 30,000 & -3.3 \\
Replicate 2 & $\mathrm{Hg}$ & 32 & 32.6 & -1.8 \\
& $\mathrm{~S}$ & 180 & 2,400 & -92.5 \\
& $\mathrm{C}$ & 30,000 & 30,000 & 0 \\
\hline
\end{tabular}


Table 7. Quality Assurance Data for Leachate Samples

\begin{tabular}{ccccc}
\hline & & & & \\
Sample No. & Replicate No. & $\mathrm{Hg}(\mu \mathrm{g} /)$ & Mean $(\mu \mathrm{g} /)$ & COV (\%) \\
\hline ZE5380619 & 1 & $<0.2$ & $<0.2$ & 0 \\
pH 2.5 & 2 & $<0.2$ & & \\
& 3 & $<0.2$ & & 0 \\
ZE5380619 & 1 & $<0.2$ & $<0.2$ & \\
pH 6.5 & 2 & $<0.2$ & & 17.2 \\
ZE5340621 & 3 & $<0.2$ & & \\
pH 2.5 & 1 & 12.0 & 10.5 & 26.8 \\
& 2 & 11.0 & & \\
ZE5340621 & 3 & 8.5 & & 48.1 \\
pH 6.5 & 1 & 5.0 & 4.87 & \\
& 2 & 6.1 & & \\
ZE3770822 & 3 & 3.5 & & \\
pH 2.5 & 1 & 1.7 & 1.1 & \\
& 2 & 0.9 & & \\
ZE3770822 & 3 & 0.7 & & \\
pH 6.5 & 1 & 0.4 & .53 & \\
& 2 & 0.5 & & \\
\hline
\end{tabular}




\section{SUMMARY AND CONCLUSIONS}

Twenty soil samples were collected from the EFPC floodplain to represent a range of biogeochemical environments and mercury contamination levels $(15-2630 \mathrm{mg} / \mathrm{kg})$. Total mercury was correlated $(r=0.84)$ with total sulfur in the twenty soils, possibly indicative of the presence of mercuric sulfide in the soils as suggested by other investigations. The soils were subjected to a leaching procedure designed to simulate the human digestive system. One of the twenty soils (ZN3210127) leached approximately $45.9 \%$ of total soil mercury while the remainder leached at most $14.2 \%$, with only five soils leaching greater than $5 \%$. The average total percent leached from the twenty soils was $5.3 \%$.

The leaching procedure was repeated for several soils at body temperature, with deoxycholic acid, a common constituent of the digestive system, and on field moist soils. The changes in percentage leached (percent leached minus percent leached at $25^{\circ} \mathrm{C}$ ) were within experimental error. Therefore, the results of the study may be extended to conditions more representative of the actual digestive system.

Less than $1 \%$ of the mercuric sulfide samples, both cinnabar and metacinnabar, leached in the procedure. In contrast, all of the mercuric chloride sample dissolved, producing leachate concentrations almost one thousand times higher than the highest soil leachate. Although the procedure is a simple representation of a complex system such as the human digestive system, the solubility and hence bioavailability of mercury in EFPC soils is obviously substantially less than pure mercuric chloride. Use of a reference dose for mercuric chloride in the EFPC risk assessment without incorporating a corresponding bioavailability factor may be unduly conservative. 


\section{REFERENCES}

Andren, A. W. and R. C. Harriss, 1975. "Observations on the association between mercury and organic matter dissolved in natural waters." Geochimica et Cosmochimica Acta. 39: 1253-1257.

Camp Dresser \& McKee. 1992. Risk Assessment, Almaden Quicksilver County Park, Final Report.

Department of Energy, 1994. East Fork Poplar Creek - Sewer Line Beltway Remedial Investigation Report. DOE/OR/02-1119\&D2.

Dobb, D., E. Miller, D. Cardenas and K. Brown, 1994. Determination of Mercury, with Speciation, in Poplar Creek Soil Samples. Environmental Protection Agency, Environmental Monitoring Systems Laboratory, Las Vegas, Nevada. Internal Report.

Huffman, E. W. D. and H. A. Stuber, 1985. "Analytical Methodology for Elemental Analysis of Humic Substances." In: Humic Substances in Soil, Sediment and Water. G. R. Aiken, D. M. McKnight and R. L. Wershaw (ed.). John Wiley \& Sons. New York. pp.433-455.

K-25 Technical Division, 1993. East Fork Poplar Creek Soils Investigation of Mercury Form and Association. Martin Marietta Energy Systems, Oak Ridge, TN. Internal Report No. Y/ER-67.

Revis, N. W., T. R. Osborne, G. Holdsworth and C. Hadden, 1989.a. "Distribution of mercury species in soil from a mercury-contaminated site." Water, Air and Soil Pollution. 45: $105-113$.

Revis, N. W., T. R. Osborne, D. Sedgley and A. King, 1989.b. "Quantitative method for determining the concentration of mercury(II) sulphide in soils and sediments." Analyst. 114: 823-825.

Revis, N. W., T. R. Osborne, G. Holdsworth and C. Hadden, 1990. "Mercury in soil: A method for assessing acceptable limits." Archives of Environmental Contamination and Toxicology. 19: 221-226. 


\section{Date: $\quad$ April 27, 1995}

To: Distribution

From: Jerome Miller, 173 Mitchell Road, MS-8252

Subject: LEFPC Bioavailability Study

Enclosed please find a report entitled Bioavailability of Mercury in East Fork Poplar Creek Soils. The data presented in this report were used to derive a bioavailability factor and human health remediation goal option (RGO) for mercury in LEFPC soils. An abbreviated version of this report was included in the addendum to the LEFPC Remedial Investigative Report (DOE/OR/0211198DE/A1/R1).

\section{DISCLAIMER}

This report was prepared as an account of work sponsored by an agency of the United States Government. Neither the United States Government nor any agency thereof, nor any of their employees, makes any warranty, express or implied, or assumes any legal liability or responsibility for the accuracy, completeness, or usefulness of any information, apparatus, product, or process disclosed, or represents that its use would not infringe privately owned rights. Reference herein to any specific commercial product, process, or service by trade name, trademark, manufacturer, or otherwise does not necessarily constitute or imply its endorsement, recommendation, or favoring by the United States Government or any agency thereof. The views and opinions of authors expressed herein do not necessarily state or reflect those of the United States Government or any agency thereof. 


\section{DISTRIBUTION}

1. L. V. Asplund

2. M. O. Barnett

3. B. A. Berven

4. R. B. Cook

5. D. G. Cope

6. S. G. Hildebrand

7. B. L. Kimmel

8-9. A. K. Lee/OSTI

10. J. M. Loar

11-13. D. M. Matteo

14-18. J. Q. Miller

19. H. C. Newsom/D. C. White

20-21. P. T. Owen

22. D. E. Reichle

23. S. H. Stow

24-30. R. R. Turner

31. Central Research Library

32. Environmental Sciences Library

33-35. ER Document Management Center

36-37. ORNL Laboratory Records

38. Y-12 ER Document Management Center

39. Y-12 Technical Library

40. Y-12 Central Files

41. J. Lea, Jacobs Engineering Group, 125 Broadway Ave., Oak Ridge, TN 37830

42. W. Tolbert, Science Applications International Corporation, 301 Laboratory Rd., Oak Ridge, TN 37830

43. D. Paye, Environmental Restoration Division, DOE Oak Ridge Operations Office, P.O. Box 2001, Oak Ridge, TN 37831-8541

44. R. C. Sleeman, Environmental Restoration Division, DOE Oak Ridge Operations Office, P.O. Box 2001, Oak Ridge, TN 37831-8541

45. S. L. Lankford, Oak Ridge Remediation Branch, DOE Oak Ridge Operations Office, P.O. Box 2001, Oak Ridge, TN 37831-8541 